\title{
PERHITUNGAN KECEPATAN SEDIMENTASI MELALUI PENDEKATAN USLE DAN PENGUKURAN KANDUNGAN TANAH DALAM AIR SUNGAI YANG MASUK KE DALAM WADUK SERMO
}

\author{
Bambang Kun Cahyono ${ }^{1}$, Lukman Hakim², Waljiyanto ${ }^{3}$, Agus Darmawan Adhi ${ }^{4}$ \\ ${ }^{1,2}$ Departemen Teknik Geodesi/Fakultas Teknik, Universitas Gadjah Mada, Indonesia \\ Email: ${ }^{1}$ bambangkun@ugm.ac.id, ${ }^{2}$ lukman.hakim.24@mail.ugm.ac.id \\ ${ }_{3}^{3}$ Departemen Teknologi Kebumian/Sekolah Vokasi, Universitas Gadjah Mada, Indonesia \\ Email:3jinto@ugm.ac.id \\ ${ }^{4}$ Departemen Teknik Sipil dan Lingkungan/Fakultas Teknik, Universitas Gadjah Mada, Indonesia \\ Email: ${ }^{4}$ agusdadi1@ugm.ac.id
}

\begin{abstract}
Dam is one of the essential man-made buildings which was developed to various beneficialy purposes such as irrigation, fresh water supply, flooding and drying control, and also tourism. Due to those mentioned functions, condition of the dam has to be maintained continuously especially from sedimentation. Sedimentation is being a serious threat for the continuity of dam services. Protecting dam from sedimentation is not only managing dam area, but also we have to care all watershed area, because the sedimentation is caused by erotion on the area. In order to know the rate of the sedimentation within the dam, measurement and prediction must be done. One of methods to predict and measure the sedimentation is by analyzing geospatial data using USLE Approach, and analyzing suspended sediment in river's water toward to the dam. By those both analysis, rate of sedimentation happened within the dam can be calculated. This paper try to use geospatial (GIS) based analysis to estimate the sedimentation rate using USLE approach within Ngrancah Watershed. The USLE Formula requires four types of maps, they are soil type, slope, land cover, and rain erosivity maps. Each of maps is classified to the specific standards, then will be analized by overlaying to another map. Another method will be used to estimate the sedimentation rate is the suspended sediment measurement. This method was determined using sediment transport formula. The data used are samples of river water ing Ngerancah Watershed that was flow toward to the Sermo Dam, and daily volume of inflow water. Those resulted values, then were compared each other. Based on the calculation, sedimentation rate resulted using USLE Approach is $276.100,917 \mathrm{~m}^{3}$ per year or $8,675 \mathrm{~mm}$ thickness per year. While the calculation based on the measurement of suspended sediment in river's water is 270.206,363 $\mathrm{m}^{3}$ per year or 8,490 mm thickness per year. The difference value between the both methods is $5894,555 \mathrm{~m}^{3}$ per year or 0,185 mm thickness per year. Based on the watershed monitoring guidelines published by The Ministry of Forestry of Indoensia, the Sermo Dam sedimentation rate is categorized in poor class, because the sedimentation rate is exceeding $5 \mathrm{~mm}$ per year, as the safe limit of dam sedimentation rate.
\end{abstract}

Keywords: sedimentation, USLE, suspended sediment, Ngrancah Watershed, Sermo Dam.

\section{PENDAHULUAN}

\subsection{Latar Belakang}

Tanah adalah sumber daya alam yang esensial bagi makhluk hidup. Tanah dapat mengalami kerusakan, salah satunya adalah erosi. Erosi yaitu peristiwa hilangnya lapisan permukaan tanah atas, baik oleh pergerakan air atau angin (Suripin, 2002). Erosi menjadi masalah serius pada pengelolaan Daerah Aliran Sungai (DAS). Selain tanah menjadi tidak produktif, erosi di DAS menimbulkan sedimentasi di sungai dan waduk. Untuk mengatasi masalah tersebut, perlu manajemen dan pengelolaan suatu DAS. Berdasarkan Keputusan Menteri Kehutanan Republik Indonesia (SK.328/Menhut-II/2009) perihal penetapan DAS prioritas, terdapat 108 DAS kirits erosi yang perlu ditangani termasuk di dalamnya adalah DAS Ngrancah yang menjadi daerah tangkapan air Waduk Sermo di Kabupaten Kulon Progo, Daerah Istimewa Yogyakarta. Keberadaan Waduk Sermo diiringi oleh perkembangan aktivitas masyarakat sekitar, baik kegiatan wisata, ekonomi, maupun aktivitas sehari-hari. Sayangnya, aktivitas ini berdampak negatif pada kondisi Waduk Sermo seperti terjadinya sedimentasi di waduk yang berakibat pada pendangkalan dan kesehatan waduk terutama dari segi aspek tata air.

Mengetahui dampak sedimentasi di Waduk Sermo, perlu diketahui nilai kecepatan sedimentasi sebagai salah satu upaya dalam pengendalian erosi dan sedimentasi. Kecepatan sedimentasi dapat ditentukan melalui pendekatan suatu metode prediksi laju erosi yang dikenal sebagai USLE (Universal Soil Loss Equation). USLE memprediksi laju erosi suatu daerah dengan mempertimbangkan beberapa faktor seperti faktor erosivitas hujan, faktor erodibilitas tanah, faktor panjang dan kemiringan lereng, faktor tutupan lahan dan konservasi lahan (Kironoto, 2003). Penggunaan USLE perlu dibandingkan untuk mengetahui kedekatan nilai prediksi kecepatan sedimentasi di Waduk Sermo dengan data hasil ukuran. Perbandingan 
dilakukan pada nilai kecepatan sedimentasi dari pengukuran kandungan tanah dalam air yang masuk ke dalam waduk berupa sampel air kadar sedimen dari sungai yang alirannya menuju Waduk Sermo. Berdasarkan nilai kecepatan sedimentasi di Waduk Sermo dari 2 metode yang digunakan, maka diharapkan pada pihak pengelola Waduk Sermo dapat mengambil kebijakan yang tepat terhadap pola pengelolaan waduk yang dilakukan sebagai upaya pengendalian sedimentasi di Waduk Sermo agar usia waduk dalam melakukan fungsinya sesuai yang direncanakan.

\subsection{Tujuan}

Makalah ini bertujuan untuk mengetahui nilai estimasi kecepatan sedimentasi di Waduk Sermo, baik dengan pendekatan USLE (Universal Soil Loss Equation) maupun metode angkutan sedimen dengan data pengukuran kandungan tanah dalam air yang masuk ke Waduk Sermo pada tahun 2015.

\subsection{Tinjauan Pustaka}

Tresnawati (1991), dalam penelitiannya menentukan pola penanaman dan tindakan konservasi yang tepat berdasarkan hasil nilai prediksi erosi dengan Metode USLE di Kecamatan Sukabumi. Setelah dilakukan perhitungan, diperoleh variasi nilai prediksi erosi sebesar 0,02-2506,16 ton/ha/tahun. Rekomendasi tindakan konservasi tanah berupa penanaman tanaman penutup tanah rendah. Hasil tersebut dipengaruhi oleh perkalian faktor erosi yang terdiri dari erosivitas hujan (R), erodibilitas tanah (K), panjang dan kemiringan lereng (LS), tanaman dan pengelolaannya (C), dan tindakan konservasi tanah (P).

Tingginya nilai prediksi erosi diakibatkan oleh intensitas curah hujan yang tinggi sehingga faktor erosivitas hujan sebagai energi kinetik hujan dalam mengerosi tanah semakin besar. Tanah dengan kandungan liat yang rendah membuat permeabilitas tanah juga rendah, menyebabkan faktor erodibilitas tanah atau kepekaan tanah terhadap erosi juga rendah. Begitu juga dengan kemiringan lereng yang curam menyebabkan pergerakan air dalam membawa partikel-partikel tanah bertambah.

Bara'tau (2012), dalam penelitiannya menentukkan muatan sedimen di DAS Tallo Hulu, menyatakan faktor curah hujan memiliki pengaruh yang sangat nyata terhadap muatan sedimen. Selain faktor penggunaan lahan dan topografi, debit sungai juga berpengaruh besar terhadap muatan sedimen pada suatu DAS maupun sub DAS.

Hermiawati (2006) dalam penelitiannya melakukan analisis perbandingan pendugaan erosi metode USLE dan observasi lapangan dengan unit Stasiun Pengamatan Aliran Sungai (SPAS) di DAS Citarum periode tahun 2003-2004, menyatakan faktor penduga erosi saling berhubungan antara satu dengan yang lainnya. Perubahan salah satu faktor erosi dapat merubah laju erosi yang terjadi, meskipun faktor lainnya berada dalam kondisi yang tetap. Hal ini memberikan USLE kemudahan dalam melakukan pendugaan erosi maupun sedimentasi.

Lazzari, dkk. (2016) juga melakukan estimasi penentuan laju sedimentasi berdasarkan perhitungan suspended sediment dan pendekatan RUSLE dan USPED di daerah bendungan artifisial Camastra di daerah Italia Selatan. Perhitungan RUSLE dan USPED dilakukan di daerah DAS Camastra, baik DAS utama maupun DAS kecil di sisi utaranya. Dengan melakukan estimasi menggunakan kedua metode pendekatan tersebut dan dibandingkan dengan data hasil pengukuran batimetri di tahun-tahun sebelumnya, kecepatan sedimentasi di DAS tersebut bisa ditentukan.

Saygin, dkk. (2014) juga telah melakukan perhitungan kecepatan sedimentasi di daerah Bendungan Irigasi Saraykoy II di Turki. Dalam paper ini digunakan pendekatan RUSLE melalui pendekatan Sediment Delivery Ratio (SDR) untuk menyatakan tingkat erosi yang terjadi di DAS dengan asumsi besar sedimentasi yang terjadi di bendungan irigasi tersebut sebanding dengan besarnya SDR terhadap erosi yang terjadi di DAS Semi-Arid. Semua faktor dan sub-faktor dalam RUSLE diestimasi menggunakan pendekatan DEM, GIS, dan Geostatistik untuk mendapatkan hasil estimasi yang baik. Berdasarkan data hasil estimasi tersebut, selanjutnya dievaluasi umur layanan waduk secara ekonomis.

\section{METODE PENELITIAN}

\subsection{Pendekatan Universal Soil Lost Equation (USLE)}

Pelaksanaan dimulai dengan mengumpulkan data-data yang dibutuhkan. Tahapan utama dalam penentuan kecepatan sedimentasi dengan pendekatan USLE yaitu delineasi watershed atau DAS Ngrancah yang menjadi batas area perhitungan laju sedimentasi Waduk Sermo. Delineasi watershed menggunakan data peta kontur yang terdiri dari garis kontur dan titik tinggi.

Delineasi watershed diawali dengan pembuatan DEM yang menyajikan ketinggian permukaan bumi secara digital. Terbentuknya DEM dilanjutkan dengan pembuatan raster flow direction dan flow accumulation. Flow direction yaitu raster yang menunjukkan arah aliran air, didasari perbedaan nilai elevasi antar piksel pada DEM, sedangkan flow accumulation merupakan raster yang menunjukkan akumulasi terkumpulnya aliran air dari piksel raster flow direction. Watershed yang terbentuk berasal dari data flow direction dan titik pour points. Titik pour points sebagai titik yang dilalui oleh aliran air, di 
definisikan di atas hulu dan pertemuan antar cabang sungai. Sungai yang terbentuk berasal dari raster flow accumulation. Terbentuknya watershed digunakan untuk menentukkan nilai prediksi laju erosi berdasarkan pada parameter persamaan USLE yang dikemukakan oleh Wischmeier dan Smith (1978) sebagaimana disajikan Persamaan 1 berikut.

$$
\mathrm{Ea}=\mathbf{R} \times \mathbf{K} \times \operatorname{LS} \times \mathbf{C} \times \mathbf{P}
$$

Keterangan: $E a$ adalah besarnya kehilangan tanah (ton/ha/tahun); $R$ adalah faktor erosivitas hujan (kJ/ha); $K$ adalah faktor erodibilitas tanah (ton/kJ); LS adalah faktor panjang dan kemiringan lereng; $C$ adalah faktor tanaman penutup lahan; $P$ adalah faktor tindakan konservasi tanah.

Faktor erosivitas hujan adalah kemampuan air hujan dalam mengerosi tanah (Arsyad, 2010). Data curah hujan Waduk Sermo dibutuhkan untuk memperoleh nilai erosivitas hujan wilayah Waduk Sermo berdasarkan Persamaan Abdurachman (1989) sebagaimana diuraikan Persamaan 2 dan 3 berikut.

$$
\begin{aligned}
& \mathrm{Rm}=\frac{(\mathrm{Pm})^{2,263} \times(\text { Max P })^{0,678}}{40,056 \times(\mathrm{Dm})^{0,349}} \\
& \mathrm{R}=\sum_{\mathrm{m}=1}^{12}\left(\mathrm{R}_{\mathrm{m}}\right)
\end{aligned}
$$

Keterangan dari persamaan tersebut: $R$ merupakan erosivitas hujan tahunan (kJ/ha); $R m$ merupakan erosivitas hujan bulanan (kJ/ha); Pm merupakan jumlah curah hujan dalam sebulan (cm); Dm merupakan jumlah hari hujan dalam sebulan (hari); MaxP merupakan curah hujan harian maksimal per bulan (cm).

Faktor erodibilitas tanah $(K)$ menunjukkan resistensi partikel tanah terhadap erosi oleh energi kinetik air hujan (Asdak, 1995). Nilai faktor $K$ di DAS Ngrancah dapat ditentukan melalui observasi lapangan atau dengan peta jenis tanah Kabupaten Kulon Progo yang nilai faktor $K$ mengacu pada Tabel 1.

Faktor panjang dan kemiringan lereng (LS) berpengaruh pada besarnya erosi. Panjang lereng mempengaruhi volume air yang mengalir sehingga kesempatan air dalam mengerosi tanah semakin besar. Kemiringan lereng mempengaruhi laju terkikisnya tanah sehingga aliran permukaan yang mengangkut tanah semakin cepat. Nilai faktor LS di DAS Ngrancah dapat ditentukan melalui observasi lapangan atau dengan peta kemiringan lereng yang merupakan turunan dari peta kontur Kabupaten Kulon Progo untuk mengetahui persentase kemiringan lereng bukit-bukit di DAS Ngrancah sehingga dapat didefinisikan nilai LS sesuai pada Tabel 2.

Tabel 1. Jenis tanah dan nilai erodibilitas tanah $(\mathbf{K})$

\begin{tabular}{ccc}
\hline No. & Jenis tanah & Nilai K \\
\hline 1 & Podsolik & 0,16 \\
2 & Grumusol & 0,21 \\
3 & Mediteran & 0,23 \\
4 & Litosol & 0,29 \\
5 & Latosol & 0,31 \\
6 & Regosol & 0,4 \\
7 & Alluvial & 0,47 \\
\hline
\end{tabular}

Sumber: Kironoto (2003)

Tabel 2. Nilai faktor LS

\begin{tabular}{cccc}
\hline No. & Kemiringan lereng & Kelas lereng & Nilai LS \\
\hline 1 & $0-8 \%$ & I & 0,4 \\
2 & $8-15 \%$ & II & 1,4 \\
3 & $15-25 \%$ & III & 3,1 \\
4 & $25-40 \%$ & IV & 6,8 \\
5 & $>40 \%$ & V & 9,5 \\
\hline
\end{tabular}

Sumber: Departemen Kehutanan (2009) 
Faktor tutupan dan konservasi lahan (CP) merupakan faktor yang terdiri dari faktor C dan faktor P. Faktor ini dijadikan satu jika data penilaian kedua faktor tersebut sama. Faktor CP mengindikasikan besarnya erosi yang dipengaruhi oleh jenis tanaman dan tindakan teknik konservasi tanah yang dilakukan. Peta tata guna lahan Kabupaten Kulon Progo menjadi sumber data untuk memperoleh nilai faktor CP di DAS Ngrancah yang mengacu pada Tabel 3 berikut.

Tabel 3. Nilai faktor tutupan dan konservasi lahan

\begin{tabular}{clc}
\hline No. & \multicolumn{1}{c}{ Tindakan konservasi tanah } & Faktor CP \\
\hline 1 & Pertanian dengan mulsa & 0,14 \\
2 & Pertanian dengan teras bangku & 0,04 \\
3 & Pertanian contour cropping & 0,14 \\
4 & Kebun campuran & 0,2 \\
5 & Tanaman pertanian padi irigasi & 0,01 \\
6 & Hutan tak terganggu & 0,1 \\
7 & Semak belukar & 0,3 \\
8 & Perladangan/tegalan & 0,28 \\
\hline
\end{tabular}

Sumber: Kironoto (2003)

Setelah kelima parameter USLE ditentukan, maka dihasilkan peta setiap parameter USLE yang di mana peta-peta tersebut akan digabung atau overlay untuk mendapatkan nilai prediksi laju erosi di DAS Ngrancah sesuai persamaan yang digunakan. Perolehan nilai laju erosi di DAS Ngrancah digunakan untuk memperoleh nilai produksi sedimen. Hal ini disebabkan karena tidak semua material erosi dari DAS sampai ke waduk. Persamaan produksi sedimen dinyatakan dalam Persamaan 4 berikut.

$$
\mathrm{SY}=\mathrm{SDR} \times \mathrm{Ea}
$$

Dalam hal ini, SY adalah produksi sedimen (sediment yield) (ton/ha); SDR adalah Sediment Delivery Ratio; Ea adalah laju erosi (ton/ha).

Produksi sedimen dipengaruhi rasio jumlah tanah yang terbawa oleh aliran sungai dan menuju ke waduk atau SDR (Sediment Delivery Ratio). Persamaan SDR dikemukakan oleh USDA (United States Department of Agriculture) tahun 1979 dan diuraikan dalam Persamaan 5 berikut.

$$
\operatorname{SDR}=0,5656 \times \mathrm{A}^{-0,11}
$$

Dalam hal ini: SDR merupakan Sediment Delivery Ratio; dan A adalah luas DAS ( $\left.\mathrm{km}^{2}\right)$.

\subsection{Pengambilan Sampel Air Sungai dan Air Irigasi}

Pengambilan sampel air dilaksanakan pada saat terjadi hujan dan tidak sedang hujan di musim penghujan, pada empat sungai sebagai inlet yaitu Sungai Ngrancah, Sungai Gelo, Sungai Lurung/Kedung Cawilan, dan Sungai Bengkok serta satu lokasi outlet, pada saluran irigasi yang keluar dari waduk. Dokumentasi pengambilan sampel air seperti pada Gambar 1.

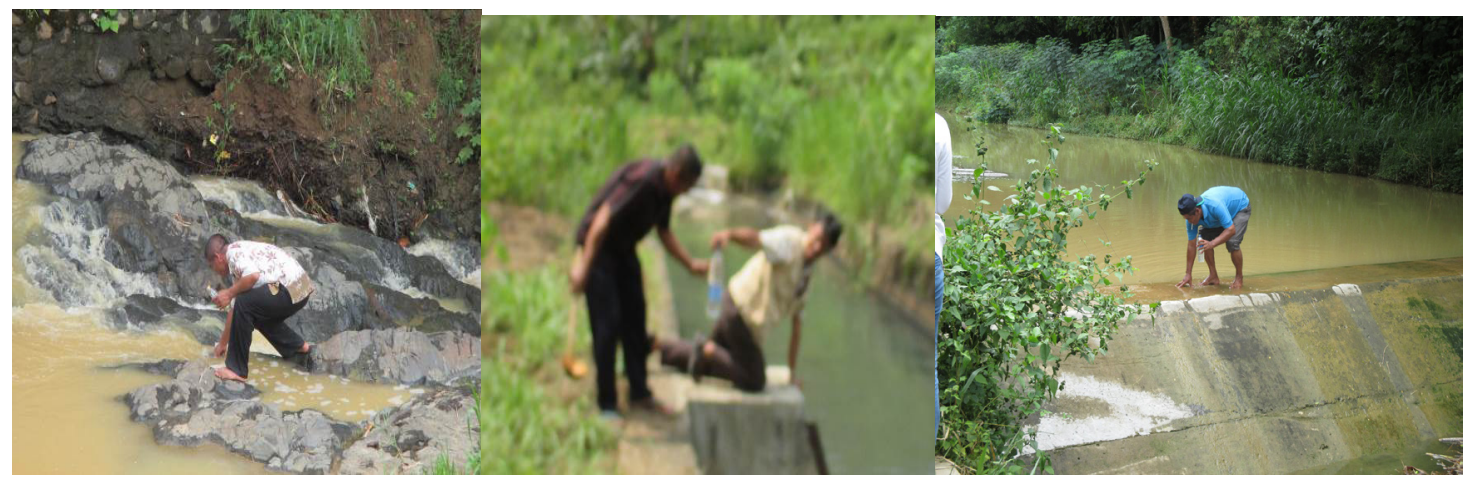

Gambar 1. Pengambilan sampel air sungai (inlet) dan saluran irigasi (outlet) 


\subsection{Pengolahan Data Suspended Sedimen}

Untuk mendapatkan data berat tanah yang terkandung dalam air sungai dan air saluran irigasi di Waduk Sermo, maka perlu dilakukan analisis suspended sediment di laboratorium. Pengujian ini akan memisahkan tanah dari air dan selanjutnya dihitung besarnya gram kandungan tanah dalam setiap liter volume air sungai. Besaran masa tanah tersebut selanjutnya diestimasi berdasarkan debit air sungai harian yang masuk ke dalam waduk menggunakan pendekatan angkutan sedimen. Adapun dokumentasi pengujian laboratorium disajikan pada Gambar 2 berikut.

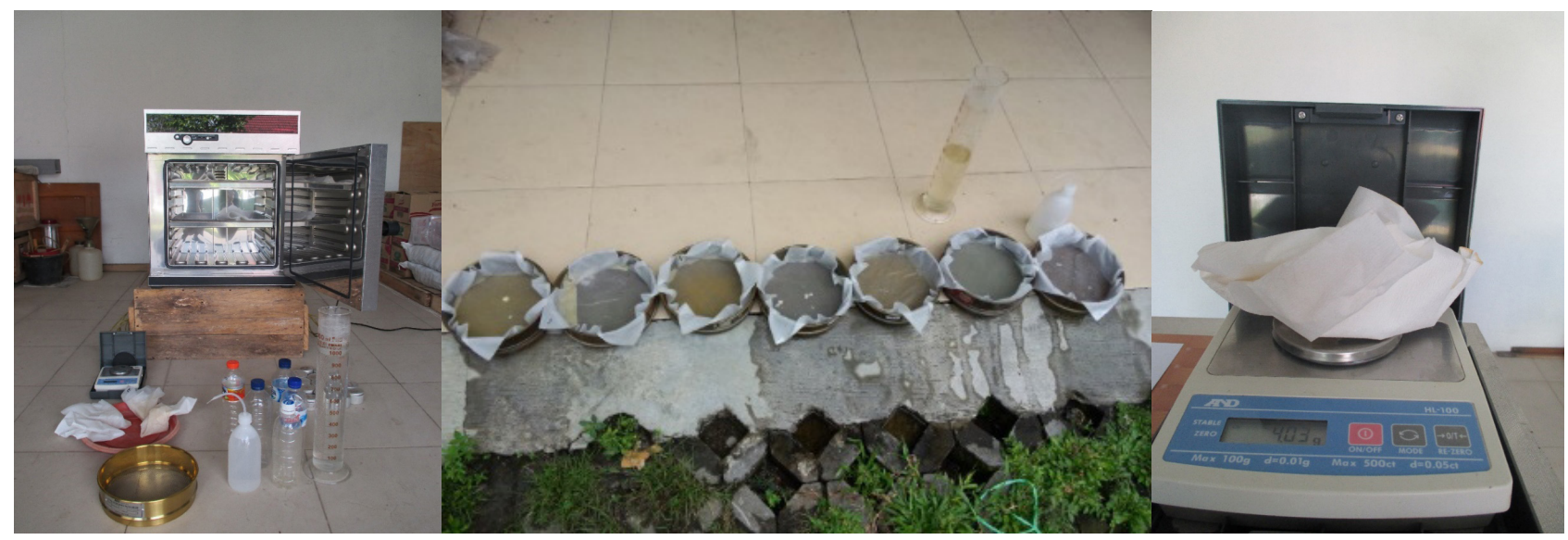

Gambar 2. Pengujian laboratorium untuk mengetahui kandungan tanah dalam air sungai

\subsection{Pendekatan Angkutan Sedimen (Suspended Sediment)}

Selain pendekatan USLE, laju sedimentasi Waduk Sermo ditentukan melalui pengukuran kandungan tanah dengan Metode Angkutan Sedimen. Data yang digunakan yaitu sampel air sungai yang menuju ke Waduk Sermo yang berisi kadar suspensi sedimen dan data debit Waduk Sermo. Persamaan dari angkutan sedimen dinyatakan dalam Persamaan 6 berikut.

$$
\mathrm{Qs}=\mathrm{k} \times \mathrm{Cs} \times \mathrm{Q}
$$

\footnotetext{
Keterangan: $Q s$ adalah debit angkutan sedimen (ton/hari); $k$ adalah konstanta (24 x 60 x $60=86400$ detik); $C s$ adalah sedimen (gr/liter); $Q$ adalah Debit air ( $\mathrm{m}^{3} /$ detik).
}

Tahapan terakhir, yaitu membandingkan kedua nilai kecepatan sedimentasi dalam bentuk volume dan ketebalan sedimen baik dengan pendekatan USLE atau Metode Angkutan Sedimen agar diketahui perbedaan nilai laju sedimentasi yang dihasilkan serta hubungan dari kedua metode tersebut. Secara garis besar tahapan pekerjaan dalam penelitian ini dipaparkan pada diagram alir yang disajikan pada Gambar 3. 


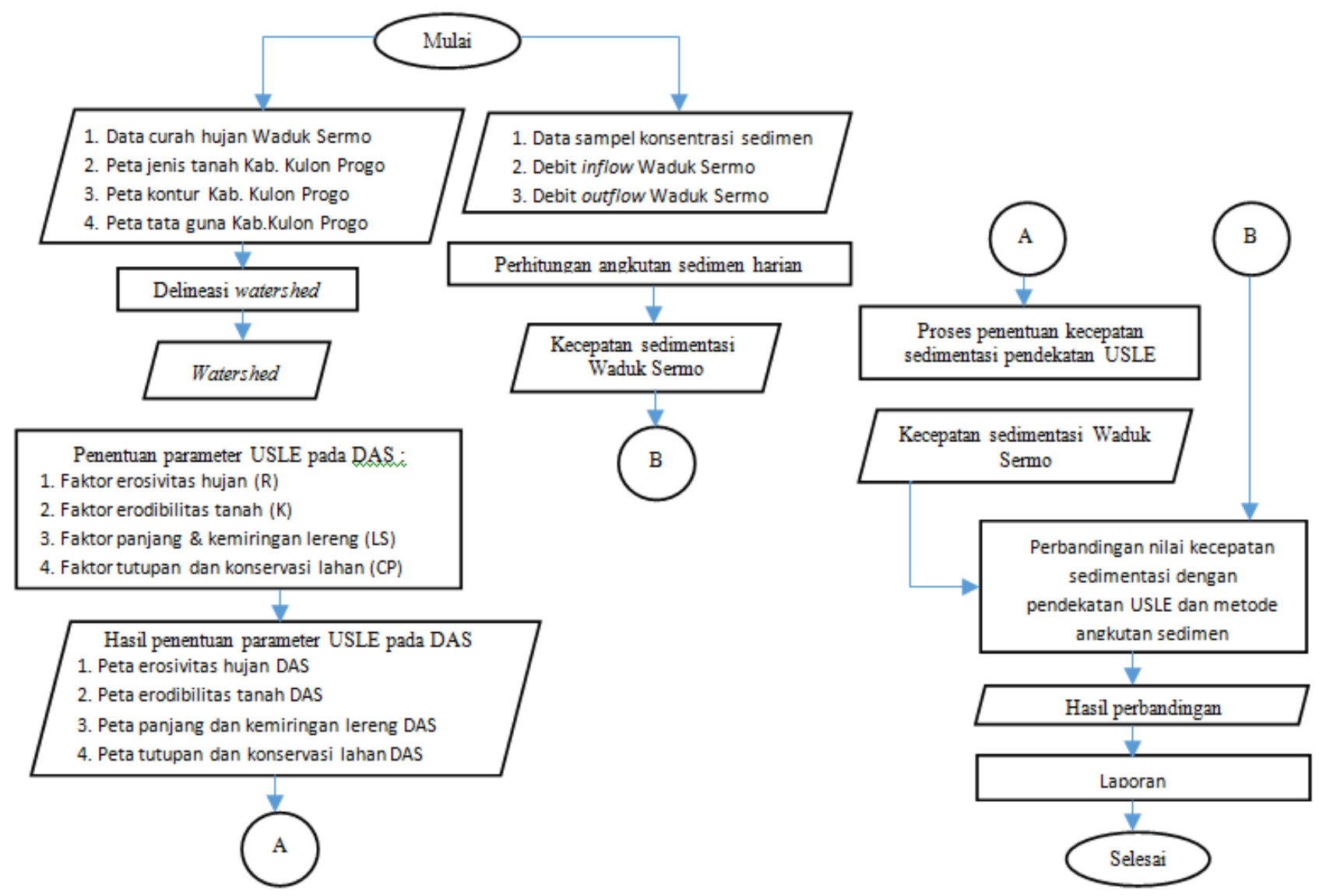

Gambar 3. Diagram Alir Penelitian.

\section{HASIL DAN PEMBAHASAN}

\subsection{Delineasi Watershed}

Pembentukkan DEM. Wilayah Kabupaten Kulon Progo merupakan daerah berbukit dengan ketinggian 100-400 m. Hal ini terlihat dari hasil pembentuk DEM (Gambar 4). Kondisi yang berbukit-bukit terutama di sebelah barat laut membuat wilayah daerah tangkapan air Waduk Sermo rawan terjadi erosi.

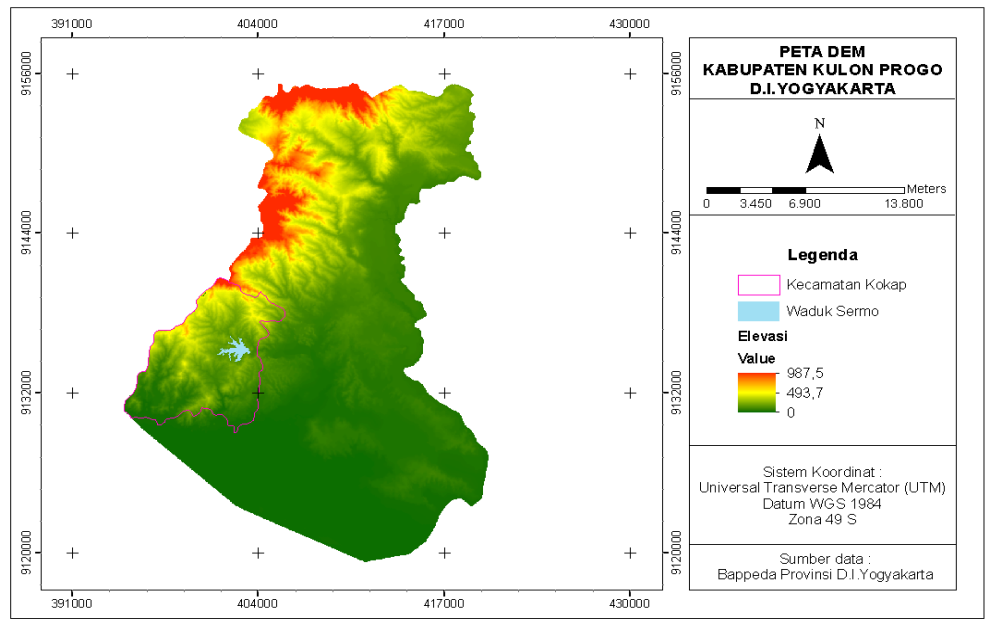

Gambar 4. DEM Kabupaten Kulon Progo 
Pembuatan raster flow direction. Pada hasil raster flow direction di Kecamatan Kokap (Gambar 5), arah aliran air menuju ke selatan dengan nilai flow direction adalah 4. Dapat dikatakan bahwa area di sisi selatan Kecamatan Kokap adalah dataran rendah.

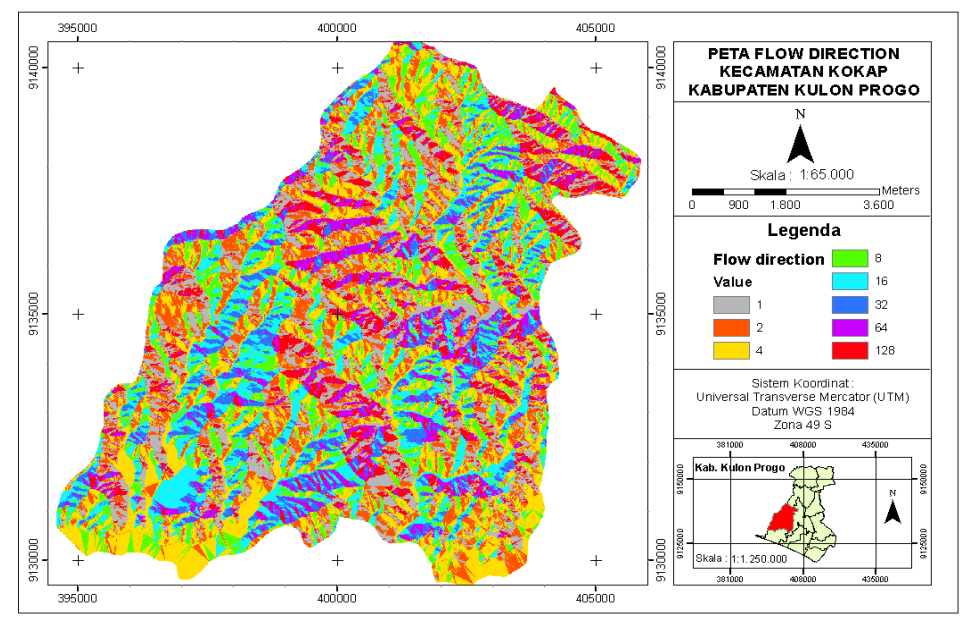

Gambar 5. Raster Flow Direction Kec. Kokap

Pembuatan raster flow accumulation. Raster flow accumulation menampilkan nilai potensi air yang terakumulasi pada suatu piksel dengan membentuk jaringan sungai. Pada Gambar 6, elevasi piksel tertinggi memiliki nilai flow accumulation 0, sebab tidak aliran air ke piksel tersebut. Elevasi piksel terendah memiliki nilaiflow accumulation tertinggi yaitu 924.678, menunjukkan 924.678 piksel mengalirkan air ke piksel tersebut.

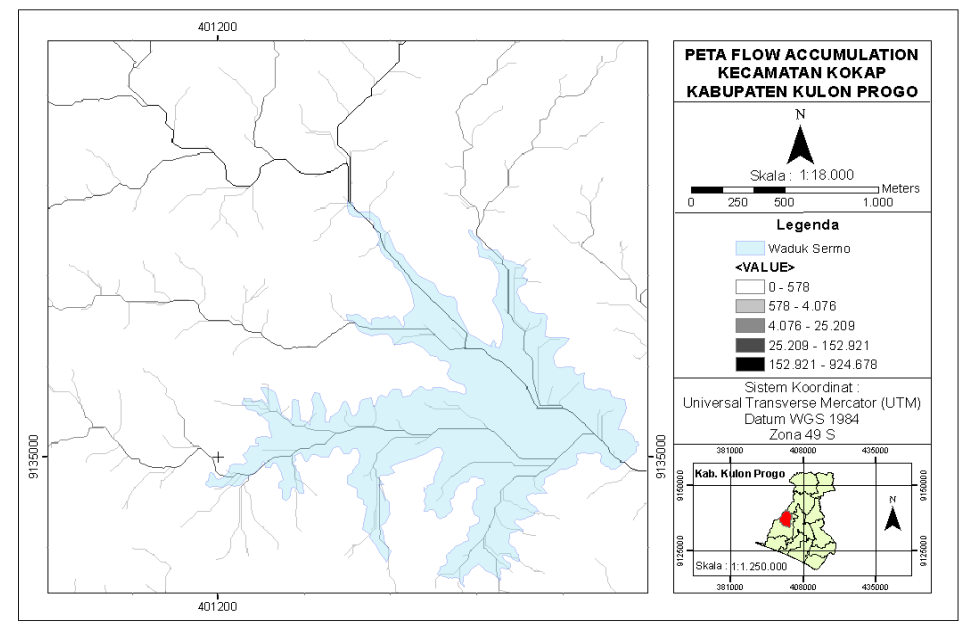

Gambar 6. Hasil raster flow accumulation

Penempatan pour points. Pour points menjadi kerangka bentuk DAS yang dihasilkan. Seperti pada Gambar 7, pour points diletakkan hulu sungai dan pertemuan cabang sungai sebab memiliki nilai flow accumulation tinggi. 


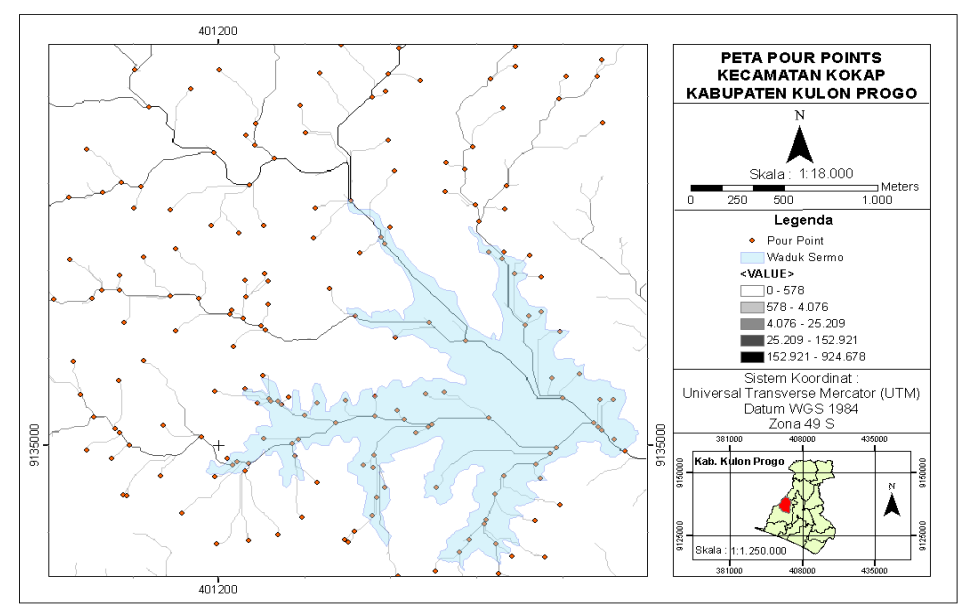

Gambar 7. Hasil penempatan pour points

Delineasi watershed. Hasil delineasi watershed yaitu terbentuknya batas DAS Ngrancah. Batas DAS yaitu garis yang ditarik melintasi kontur yang menghubungkan ketinggian tertinggi di sekitar area dimana titik pour points didefinisikan. Dari Gambar 8, terlihat batas DAS merupakan punggung bukit

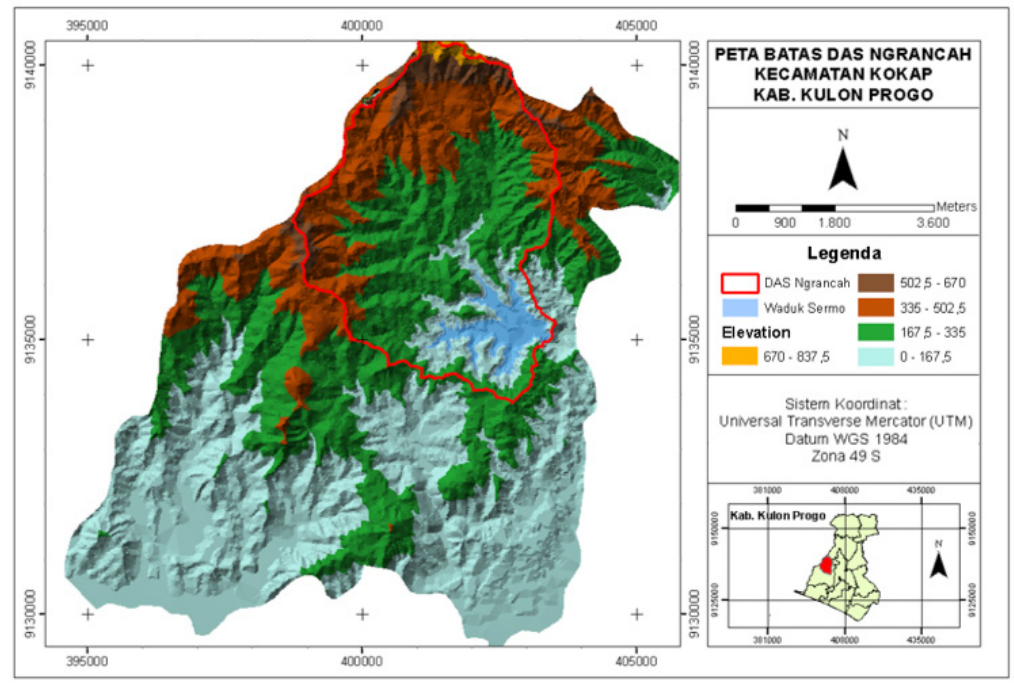

Gambar 8. Batas DAS Ngrancah hasil delineasi

\subsection{Erosivitas Hujan}

Erosivitas hujan yaitu kemampuan air hujan mengerosi tanah. Perolehan data curah hujan Waduk Sermo dicatat oleh satu stasiun, sebab stasiun tersebut mencakup radius $20 \mathrm{~km}$ sehingga curah hujan sama. Perhitungan diawali mencari erosivitas hujan bulanan dengan Persamaan 2, lalu dicari erosivitas hujan tahunan yaitu total erosivitas hujan bulanan. Hasil perhitungan nilai erosivitas hujan di DAS Ngrancah tahun 2015 pada Tabel 4. 
Tabel 4. Nilai erosivitas hujan di DAS Ngrancah 2015

\begin{tabular}{lc}
\hline \multicolumn{1}{c}{ Bulan } & Nilai faktor erosivitas hujan (kJ/ha) \\
\hline Januari & 168,018 \\
Februari & 13,354 \\
Maret & 167,496 \\
April & 302,386 \\
Mei & 1,942 \\
Juni & 0,006 \\
Juli & 0,000 \\
Agustus & 0,000 \\
September & 0,000 \\
Oktober & 0,000 \\
November & 6,539 \\
Desember & 187,715 \\
Total & 847.456 \\
\hline
\end{tabular}

\subsection{Erodibiltas Tanah}

Erodibilitas tanah $(\mathrm{K})$ adalah mudah atau tidaknya suatu tanah tererosi oleh air hujan. Hasil penilaian faktor erodibilitas tanah di DAS Ngrancah terdapat pada Gambar 9. Jenis tanah di DAS Ngrancah adalah latosol. Jenis tanah latosol termasuk jenis tanah yang sulit tererosi oleh air hujan, disebabkan jenis tanah latosol merupakan tanah lempung liat.

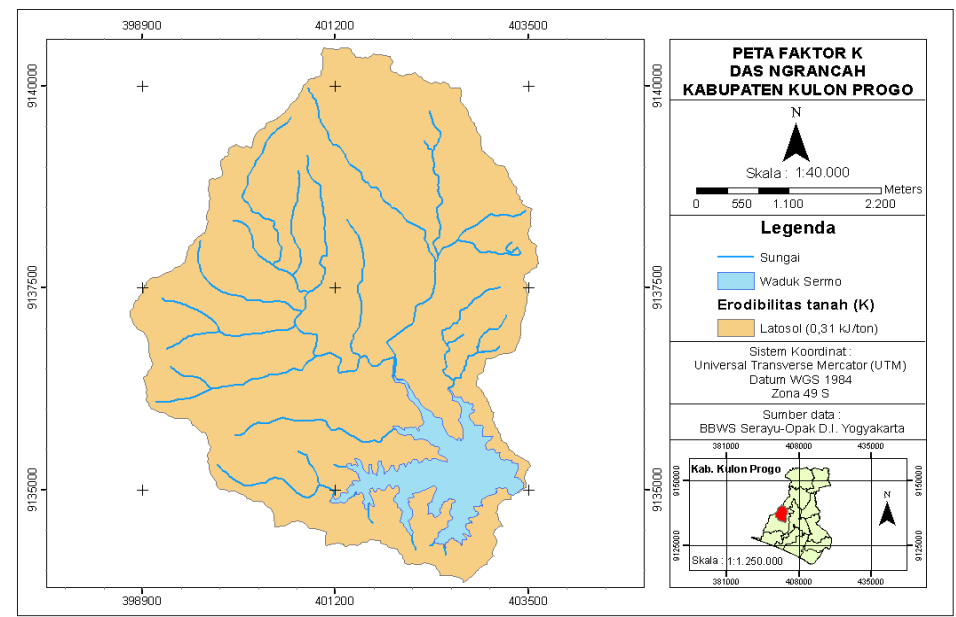

Gambar 9. Peta faktor $K$ DAS Ngrancah

\subsection{Panjang dan Kemiringan Lereng}

Kondisi topografi DAS Ngrancah didominasi dengan bentang alam yang datar hingga berbukit. Hal ini terlihat dari hasil penilaian faktor LS pada Gambar 10. 


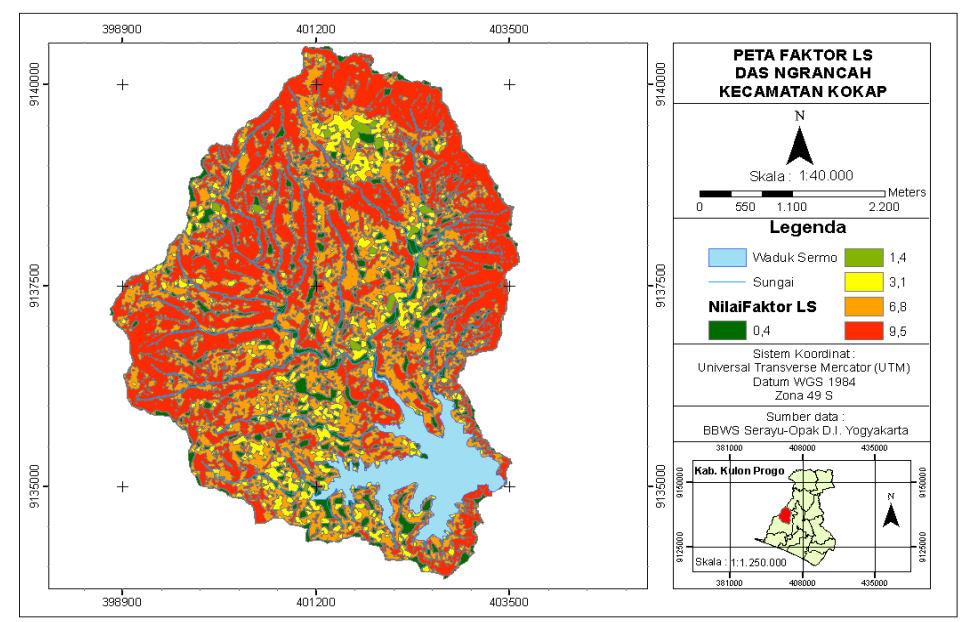

Gambar 10. Peta faktor LS di DAS Ngrancah

Peta faktor LS tersebut memuat nilai faktor LS mengacu Tabel 6. Luas dan nilai kemiringan lereng DAS Ngrancah terdapat di Tabel 5.

Tabel 5. Nilai faktor LS dan luasan di DAS Ngrancah

\begin{tabular}{cccccc}
\hline No. & $\begin{array}{c}\text { Kemiringan } \\
\text { lereng }\end{array}$ & $\begin{array}{c}\text { Kelas } \\
\text { lereng }\end{array}$ & $\begin{array}{c}\text { Nilai } \\
\text { faktor LS }\end{array}$ & Luas (ha) & $\begin{array}{c}\text { Presentase } \\
\text { luas (\%) }\end{array}$ \\
\hline 1 & $0-8 \%$ & I & 0,4 & 253,72 & 12,04 \\
2 & $8-15 \%$ & II & 1,4 & 77,40 & 3,67 \\
3 & $15-25 \%$ & III & 3,1 & 253,18 & 12,01 \\
4 & $25-40 \%$ & IV & 6,8 & 638,19 & 30,28 \\
5 & $>40 \%$ & V & 9,5 & 885,39 & 42,00 \\
\hline
\end{tabular}

\subsection{Tutupan dan Konservasi Lahan}

Penilaian faktor ini dilakukan bersamaan, sebab data tindakan konservasi lahan tidak tersedia. Hasil penilaian faktor CP di DAS Ngrancah pada Gambar 11 dan Tabel 6.

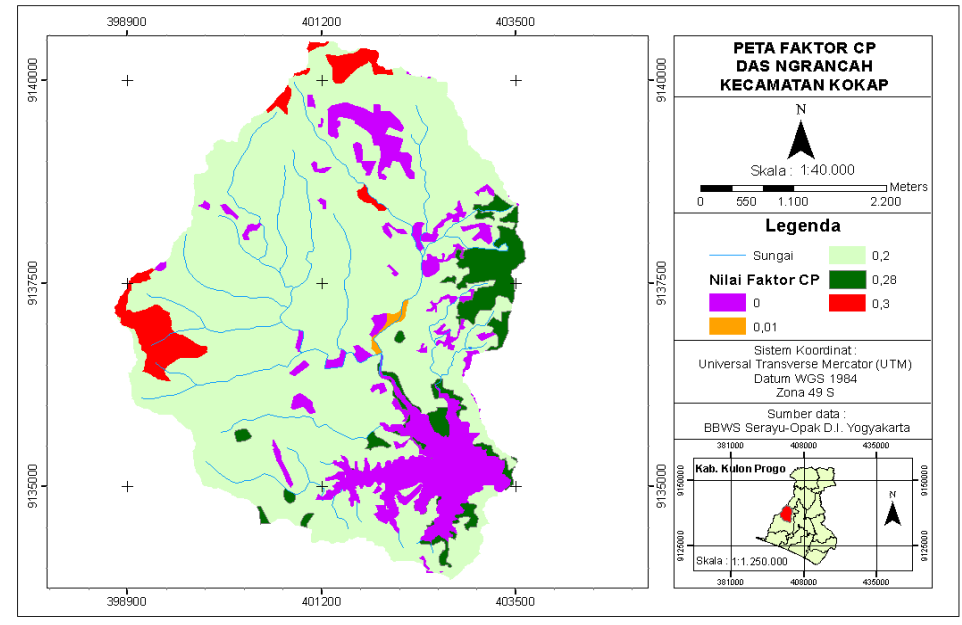

Gambar 11. Peta faktor CP di DAS Ngrancah 
Pada Gambar 11 dan Tabel 6, penggunaan lahan terluas di DAS Ngrancah adalah kebun campuran yaitu 1645,38 ha atau 78,05\% luas DAS Ngrancah. Dengan prinsip konservasi tanah seperti teras, kebun campuran dapat memperlambat laju aliran permukaan air.

Tabel 6. Nilai faktor CP beserta luasan daerah

\begin{tabular}{ccccc}
\hline \multirow{2}{*}{ No. } & \multirow{2}{*}{$\begin{array}{c}\text { Penggunaan } \\
\text { lahan }\end{array}$} & Faktor CP & \multicolumn{2}{c}{ Luas } \\
\cline { 4 - 5 } 1 & Waduk & 0 & 147,23 & 6,98 \\
2 & Kebun campuran & 0,2 & 1645,38 & 78,05 \\
3 & Pemukiman & 0 & 124,21 & 5,89 \\
4 & Sawah & 0,01 & 5,40 & 0,26 \\
5 & Semak belukar & 0,3 & 76,78 & 3,64 \\
6 & Tegalan & 0,28 & 109,03 & 5,17 \\
\hline
\end{tabular}

\subsection{Laju Sedimentasi Waduk Sermo Pendekatan USLE}

Penentuan kecepatan sedimentasi Waduk Sermo secara tak langsung ditentukan berdasarkan nilai prediksi laju erosi di DAS Ngrancah. Nilai prediksi laju erosi DAS Ngrancah diperoleh dengan cara perkalian parameter persamaan USLE yang hasilnya disajikan pada Tabel 7.

Tabel 7. Prediksi laju erosi DAS Ngrancah 2015

\begin{tabular}{|c|c|c|c|c|c|c|c|}
\hline $\begin{array}{c}\text { Tata guna } \\
\text { lahan }\end{array}$ & $\begin{array}{c}\mathbf{R} \\
\text { (kJ/ha) }\end{array}$ & $\begin{array}{c}\mathrm{K} \\
\text { (kJ/ha) }\end{array}$ & LS & $\mathbf{C P}$ & $\begin{array}{c}\text { Ea } \\
\text { (ton/ha/thn) }\end{array}$ & $\begin{array}{c}\text { Luas } \\
\text { (ha) }\end{array}$ & $\begin{array}{l}\text { Ea x luas } \\
\text { (ton/thn) }\end{array}$ \\
\hline $\mathrm{KC}$ & 847,46 & 0,31 & 6,8 & 0,2 & 357,288 & 539,324 & 192693,799 \\
\hline $\mathrm{KC}$ & 847,46 & 0,31 & 1,4 & 0,2 & 73,559 & 46,697 & 3434,980 \\
\hline $\mathrm{KC}$ & 847,46 & 0,31 & 0,4 & 0,2 & 21,017 & 159,899 & 3360,584 \\
\hline $\mathrm{KC}$ & 847,46 & 0,31 & 3,1 & 0,2 & 162,881 & 177,504 & 28912,052 \\
\hline $\mathrm{KC}$ & 847,46 & 0,31 & 9,5 & 0,2 & 499,152 & 721,119 & 359947,88 \\
\hline SB & 847,46 & 0,31 & 6,8 & 0,3 & 535,931 & 8,889 & 4764,072 \\
\hline SB & 847,46 & 0,31 & 1,4 & 0,3 & 110,339 & 0,693 & 76,455 \\
\hline SB & 847,46 & 0,31 & 0,4 & 0,3 & 31,525 & 2,859 & 90,141 \\
\hline SB & 847,46 & 0,31 & 3,1 & 0,3 & 244,322 & 1,630 & 398,276 \\
\hline SB & 847,46 & 0,31 & 9,5 & 0,3 & 748,728 & 62,563 & 46842,955 \\
\hline $\mathrm{P}$ & 847,46 & 0,31 & 6,8 & 0 & 0,000 & 39,654 & 0,000 \\
\hline $\mathrm{P}$ & 847,46 & 0,31 & 1,4 & 0 & 0,000 & 11,958 & 0,000 \\
\hline $\mathrm{P}$ & 847,46 & 0,31 & 0,4 & 0 & 0,000 & 18,818 & 0,000 \\
\hline $\mathrm{P}$ & 847,46 & 0,31 & 3,1 & 0 & 0,000 & 31,058 & 0,000 \\
\hline $\mathrm{P}$ & 847,46 & 0,31 & 9,5 & 0 & 0,000 & 22,662 & 0,000 \\
\hline $\mathrm{T}$ & 847,46 & 0,31 & 6,8 & 0,28 & 500,203 & 21,261 & 10635,010 \\
\hline $\mathrm{T}$ & 847,46 & 0,31 & 1,4 & 0,28 & 102,983 & 1,779 & 183,178 \\
\hline $\mathrm{T}$ & 847,46 & 0,31 & 0,4 & 0,28 & 29,424 & 8,017 & 235,893 \\
\hline $\mathrm{T}$ & 847,46 & 0,31 & 3,1 & 0,28 & 228,034 & 6,189 & 1411,405 \\
\hline $\mathrm{T}$ & 847,46 & 0,31 & 9,5 & 0,28 & 698,813 & 71,68 & 50090,747 \\
\hline S & 847,46 & 0,31 & 6,8 & 0,01 & 17,864 & 0,576 & 10,284 \\
\hline $\mathrm{S}$ & 847,46 & 0,31 & 1,4 & 0,01 & 3,678 & 0,59 & 2,170 \\
\hline $\mathrm{S}$ & 847,46 & 0,31 & 0,4 & 0,01 & 1,051 & 2,547 & 2,677 \\
\hline $\mathrm{S}$ & 847,46 & 0,31 & 3,1 & 0,01 & 8,144 & 1,686 & 13,733 \\
\hline
\end{tabular}


Lanjutan Tabel 7. Prediksi laju erosi DAS Ngrancah 2015

\begin{tabular}{cccccccc}
\hline $\begin{array}{c}\text { Tata guna } \\
\text { lahan }\end{array}$ & $\begin{array}{c}\mathbf{R}(\mathbf{k J} / \\
\mathbf{h a})\end{array}$ & $\begin{array}{c}\mathbf{K}(\mathbf{k J} / \\
\mathbf{h a})\end{array}$ & $\mathbf{L S}$ & $\mathbf{C P}$ & $\begin{array}{c}\text { Ea (ton/ha/ } \\
\text { thn) }\end{array}$ & Luas (ha) & $\begin{array}{c}\text { Ea } \mathbf{x} \text { luas } \\
\text { (ton/thn) }\end{array}$ \\
\hline $\mathrm{W}$ & 847,46 & 0,31 & 6,8 & 0 & 0,000 & 28,284 & 0,000 \\
$\mathrm{~W}$ & 847,46 & 0,31 & 1,4 & 0 & 0,000 & 15,558 & 0,000 \\
$\mathrm{~W}$ & 847,46 & 0,31 & 0,4 & 0 & 0,000 & 61,14 & 0,000 \\
$\mathrm{~W}$ & 847,46 & 0,31 & 3,1 & 0 & 0,000 & 34,882 & 0,000 \\
$\mathrm{~W}$ & 847,46 & 0,31 & 9,5 & 0 & 0,000 & 7,301 & 0,000 \\
& & & & 4374,935 & 2106,818 & 703106,294 \\
\hline
\end{tabular}

Keterangan: $\mathrm{KC}=$ Kebun Campuran, $\mathrm{SB}=$ Semak Belukar, $\mathrm{P}=$ Pemukiman, $\mathrm{T}=$ Tegalan, $\mathrm{S}=$ Sawah, $\mathrm{W}=$ Waduk

Pada Tabel 7 di atas, diperoleh nilai prediksi laju erosi DAS Ngrancah yaitu 4374,935 ton/ha/tahun atau 703.106,294 ton/tahun. Melalui Persamaan 3, produksi sedimen diperoleh dengan perkalian nilai laju prediksi erosi DAS Ngrancah dan nilai SDR (Sediment Delivery Ratio). Nilai SDR ditentukan melalui persamaan 4 dengan parameter persamaan yang digunakan, yaitu luas DAS Ngrancah sebesar 21,08 $\mathrm{km}^{2}$ dan hasil nilai SDR sebesar 0,4045. Nilai produksi sedimen diperoleh, yaitu 284.383,944 ton/tahun. Nilai tersebut dikonversi ke satuan laju sedimentasi dalam volume ( $\mathrm{m}^{3} / \mathrm{tahun}$ ) dengan pembagi masa jenis sedimen yaitu 1,03 ton $/ \mathrm{m}^{3}$ (uji laboratorium) sehingga laju sedimentasi Waduk Sermo dengan USLE sebesar $276.100,917 \mathrm{~m}^{3} /$ tahun

\subsection{Hasil Analisis Kandungan Tanah pada Air Sungai yang Masuk ke Waduk Sermo}

Berdasarkan data hasil uji analisis kandungan tanah dalam air sungai (inlet) dan air saluran irigasi (outlet) didapatkan data sebagaimana yang tersaji pada tabel 8 berikut:

Tabel 8. Data hasil analisis kandungan tanah dalam air sungai dan air saluran irigasi

\begin{tabular}{llccccccc}
\hline \multirow{2}{*}{$\begin{array}{l}\text { No. } \\
\text { Uji }\end{array}$} & \multicolumn{1}{c}{ Lokasi } & Volume & $\mathbf{M 1}$ & $\mathbf{M 2}$ & $\mathbf{M s}$ & \multicolumn{2}{c}{ Kandungan sedimen } \\
\cline { 3 - 7 } & & $\mathbf{C c}$ & $\mathbf{g}$ & $\mathbf{g}$ & $\mathbf{g}$ & $\mathbf{g} / \mathbf{l t}$ & $\mathbf{g} / \mathbf{m}^{\mathbf{3}}$ \\
\hline 1 & Sungai Ngrancah Menguri & 620 & 4,04 & 4,2 & 0,16 & 0,258 & 258,06 \\
2 & Sungai Ngrancah Plaosan & 532 & 3,97 & 4,11 & 0,14 & 0,263 & 263,16 \\
3 & Sungai Gelo & 610 & 3,98 & 4,22 & 0,24 & 0,393 & 393,44 \\
4 & Ngrancah Bendung & 530 & 3,95 & 4,15 & 0,20 & 0,377 & 377,36 \\
5 & Sungai Lurung/Kedung Cawilan & 595 & 3,89 & 4,08 & 0,19 & 0,319 & 319,33 \\
6 & Sungai Bengkok & 871 & 4,05 & 4,3 & 0,25 & 0,287 & 287,03 \\
\hline & & & & & Rerata $=$ & 0,316 & 316,40 \\
\hline 7 & Outlet & 1513 & 3,98 & 4,06 & 0,08 & 0,053 & 13,29 \\
\hline
\end{tabular}

Berdasarkan data yang disajikan pada Tabel 8 tersebut, diketahui bahwasannya kandungan sedimentasi tertinggi didapatkan pada Sungai Gelo dengan kandungan sedimen sebesar 393 gr $/ \mathrm{m}^{3}$. Hal ini diakibatkan karena banyaknya sedimentasi yang terjadi di DAS sungai tersebut. Hal yang hampir sama juga terjadi pada Sungai Lurung dengan kandungan sedimen sebesar $319 \mathrm{gr} / \mathrm{m}^{3}$. Yang sedikit aneh adalah data yang terjadi pada Sungai Ngrancah. Pada Sungai Ngrancah, baik dari Saluran Menguri maupun Saluran Plaosan, kandungan sedimentasi yang ada tidak setinggi pada daerah dekat bendungan. Hal ini bisa jadi diakibatkan karena kolam tangkapan sedimentasi telah penuh terisi sedimentasi sehingga yang terukur oleh tim adalah sedimentasi yang terlarut arus air sungai yang deras masuk ke waduk.

\subsection{Laju Sedimentasi Waduk Sermo Metode Angkutan Sedimen}

Laju sedimentasi metode ini menggunakan sampel air di sungai-sungai menuju Waduk Sermo. Melalui Persamaan 5, perkalian debit air dengan konsentrasi sedimen (Cs) menghasilkan nilai debit angkutan sedimen (Qs). Nilai konsentrasi sedimen terbagi atas dua, yaitu 0,316 gr/L (rerata nilai Cs di sungai) dan 0,053 gr/L (outlet). Selisih nilai Qs yang masuk ke dan keluar dari Waduk Sermo menghasilkan jumlah debit angkutan sedimen yang tersuspensi di dalam waduk. Nilai debit angkutan sedimen di Waduk Sermo periode tahun 2015 terdapat pada Tabel 9. 
Tabel 9. Nilai Qs di Waduk Sermo tahun 2015

\begin{tabular}{lccc}
\hline \multicolumn{1}{c}{ Bulan } & $\begin{array}{c}\text { Qs inflow } \\
\text { (ton/bulan) }\end{array}$ & $\begin{array}{c}\text { Qs outflow } \\
\text { (ton/bulan) }\end{array}$ & $\begin{array}{c}\text { Selisih } \\
\text { (ton/bulan) }\end{array}$ \\
\hline Januari & 2591,455 & 71,92 & 2519,535 \\
Februari & 656,371 & 33,79 & 622,581 \\
Maret & 2885,367 & 100,012 & 2785,355 \\
April & 3953,465 & 166,479 & 3786,986 \\
Mei & 784,734 & 67,161 & 717,573 \\
Juni & 113,386 & 28,831 & 84,555 \\
Juli & 13,783 & 6,569 & 7,214 \\
Agustus & 26,931 & 10,791 & 16,140 \\
September & 26,192 & 7,983 & 18,208 \\
Oktober & 123,376 & 44,188 & 79,187 \\
November & 282,043 & 61,638 & 220,405 \\
Desember & 1417,436 & 22,043 & 1395,393 \\
Jumlah (ton/tahun) & 12874,538 & 621,406 & 12253,133 \\
Volume (m 3 /tahun) & 270206,363 & 13401,849 & 257164,514 \\
\hline
\end{tabular}

Keterangan: *berat jenis padatan sedimen $=0,048$ ton $/ \mathrm{m}^{3}$

\subsection{Perbandingan Kecepatan Sedimentasi USLE dan Angkutan Sedimen}

USLE diharapkan menjadi metode yang tepat untuk memprediksi laju sedimentasi sebagai upaya pengendalian erosi dan sedimentasi. Oleh sebab itu, perlu dilakukan perbandingan laju sedimentasi dari pengukuran sedimen di lapangan. Perbandingan nilai laju sedimentasi Waduk Sermo terdapat pada Tabel 10.

Tabel 10. Perbandingan nilai laju sedimentasi USLE dan angkutan sedimen

\begin{tabular}{lccc}
\hline \multirow{2}{*}{ Bulan } & \multicolumn{2}{c}{ Kecepatan sedimentasi (ton/bulan) } & \multirow{2}{*}{$\begin{array}{c}\text { Selisih } \\
\text { (ton/bulan) }\end{array}$} \\
\cline { 2 - 3 } & USLE & Angkutan sedimen & 351,707 \\
Januari & 54740,279 & 54388,572 & $-9424,899$ \\
Februari & 4350,791 & 13775,69 & $-5987,035$ \\
Maret & 54570,041 & 60557,076 & 15543,370 \\
April & 98517,316 & 82973,946 & $-15836,94$ \\
Mei & 632,796 & 16469,736 & $-2377,867$ \\
Juni & 1,847 & 2379,714 & $-289,265$ \\
Juli & 0,001 & 289,266 & $-565,209$ \\
Agustus & 0,000 & 565,209 & $-549,699$ \\
September & 0,000 & 549,699 & $-2589,365$ \\
Oktober & 0,000 & 2589,365 & $-3789,154$ \\
November & 2130,270 & 5919,424 & 31408,911 \\
Desember & 61157,577 & 29748,666 & 5894,555 \\
Total (ton/tahun) & 276100,917 & 270206,363 & 491,213 \\
Rata-rata (ton/bulan) & 23008,410 & 22517,197 & \\
\hline
\end{tabular}

Dari tabel di atas, selisih laju sedimentasi kedua metode adalah 5894,555 $\mathrm{m}^{3} /$ tahun. USLE memprediksi laju sedimentasi yang masuk ke waduk sehingga pada perbandingan digunakan laju sedimentasi angkutan sedimen berdasarkan debit inflow saja. Perbandingan juga disajikan dalam bentuk grafik pada Gambar 12. 


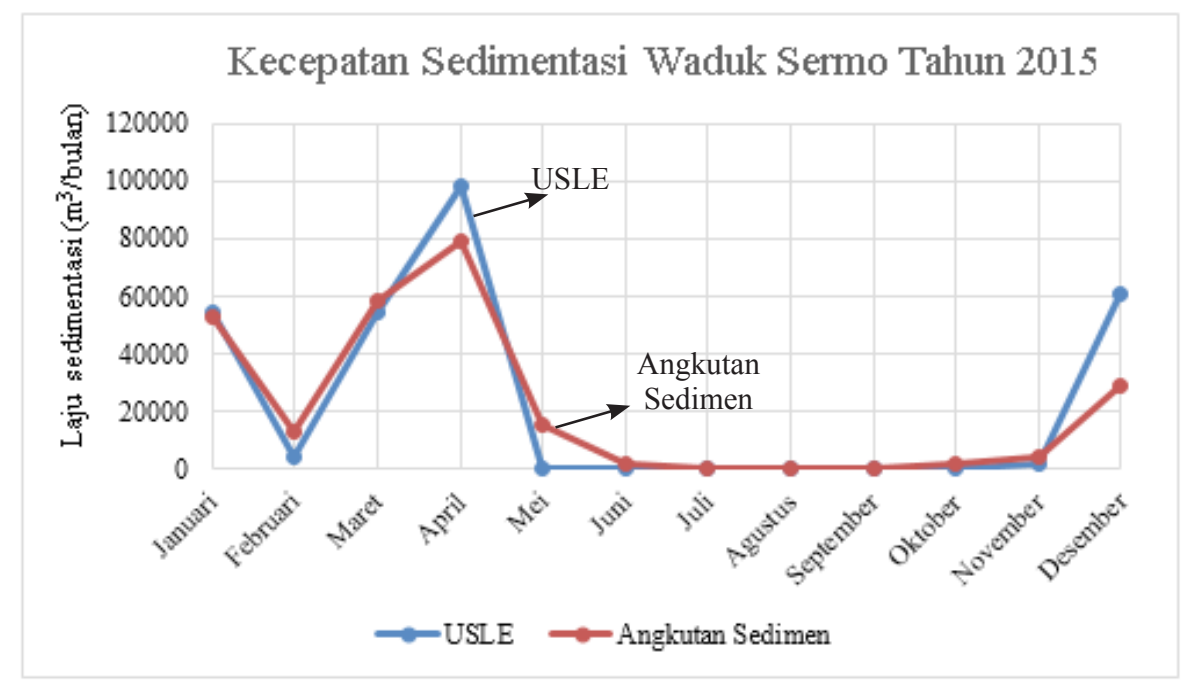

Gambar 12. Grafik laju sedimentasi Waduk Sermo

Dari grafik di atas, pola bentuk grafik yang dihasilkan dari kedua metode sama. Hal ini berarti pada bulan di mana kecepatan sedimentasi mengalami kenaikan atau penurunan, keduanya mengindikasikan hal yang sama. Nilai kecepatan sedimentasi Waduk Sermo dikonversi menjadi laju ketebalan sedimen yang dihasilkan dari hasil bagi laju sedimentasi $\left(\mathrm{m}^{3} /\right.$ tahun) dan luas Waduk Sermo $\left(\mathrm{m}^{2}\right)$ seperti pada Tabel 11.

Tabel 11. Laju ketebalan sedimen di Waduk Sermo.

\begin{tabular}{lccc}
\hline \multirow{2}{*}{ Bulan } & \multicolumn{2}{c}{ Laju ketebalan sedimen (mm/bulan) } & $\begin{array}{c}\text { Selisih } \\
\text { (mm/bulan) }\end{array}$ \\
\cline { 2 - 3 } Januari & 1,72 & 1,709 & 0,011 \\
Februari & 0,137 & 0,433 & $-0,296$ \\
Maret & 1,715 & 1,903 & $-0,188$ \\
April & 3,095 & 2,607 & 0,488 \\
Mei & 0,02 & 0,517 & $-0,498$ \\
Juni & 0,000 & 0,075 & $-0,075$ \\
Juli & 0,000 & 0,009 & $-0,009$ \\
Agustus & 0,000 & 0,018 & $-0,018$ \\
September & 0,000 & 0,017 & $-0,017$ \\
Oktober & 0,000 & 0,081 & $-0,081$ \\
November & 0,067 & 0,186 & $-0,0119$ \\
Desember & 1,922 & 0,935 & 0,987 \\
Total (mm/tahun) & 8,675 & 8,490 & 0,185 \\
Rata-rata (mm/bulan) & 0,723 & 0,707 & 0,015 \\
\hline
\end{tabular}

Ketebalan sedimen pada Tabel 11 diasumsikan merata di setiap sisi Waduk Sermo, karena pada kondisi nyata intensitas laju ketebalan sedimen di Waduk Sermo berbeda-beda di setiap sisi waduk. Besaran laju sedimentasi diklasifikasikan sesuai ketebalan sedimen yang dihasilkan per tahun baik di sungai maupun di waduk berdasarkan pada peraturan direktur jendral rehabilitasi lahan dan perhutanan sosial nomor P.04/V-SET/2009 perihal pedoman monitoring dan evaluasi daerah aliran sungai yang dikeluarkan oleh Departemen Kehutanan pada Tabel 12. 
Tabel 12. Klasifikasi tingkat laju sedimentasi

\begin{tabular}{ccc}
\hline No. & $\begin{array}{c}\text { Laju sedimentasi } \\
(\mathbf{m m} / \text { tahun })\end{array}$ & Kelas \\
\hline 1 & $<2$ & Baik \\
2 & $2-5$ & Sedang \\
3 & $>5$ & Buruk \\
\hline
\end{tabular}

Sumber: Departemen Kehutanan (2009)

Berdasarkan Keputusan tersebut dikatakan DAS Ngrancah sebagai daerah tangkapan air Waduk Sermo termasuk salah satu DAS dengan kategori kritis erosi. Hal ini dibuktikan dari hasil laju ketebalan sedimentasi Waduk Sermo yang apabila mengacu Tabel 5, maka tingkat laju sedimentasi Waduk Sermo pada kategori kelas buruk disebabkan laju sedimentasi Waduk Sermo melebihi batas aman yaitu $<5 \mathrm{~mm} /$ tahun.

\section{KESIMPULAN DAN SARAN}

\subsection{Kesimpulan}

Berdasarkan apa yang telah dihasilkan dan disajikan dalam makalah ini, bisa disimpulkan bahwa kecepatan sedimentasi Waduk Sermo pada tahun 2015 dengan pendekatan USLE adalah 276.100,917 m³/tahun atau dalam ketebalan sedimen sebesar 8,675 mm/tahun. Adapun hasil perhitungan berdasarkan data pengukuran kandungan tanah dalam air adalah $270.206,363 \mathrm{~m}^{3} /$ tahun atau $8,490 \mathrm{~mm} /$ tahun. Berdasarkan kedua data hasil pengukuran menggunakan dua metode pendekatan tersebut memang didapatkan perbedaan data, akan tetapi perbedaan tersebut hanya $5.894,544 \mathrm{~m}^{3} /$ tahun saja atau sekitar $2 \%$ dari total sedimentasi yang terjadi.

\subsection{Saran}

Untuk mendapatkan data pembanding lainnya, alangkah lebih baiknya apabila dilakukan metode ketiga yang digunakan untuk mengevaluasi sedimentasi yang terjadi sehingga dengan lebih banyak metode yang ada, maka kecepatan sedimentasi pada Waduk Sermo akan lebih bisa dipercaya. Salah satu metode yang bisa diterapkan untuk evaluasi sedimentasi adalah Metode Batimetri Multi Epoch.

\section{UCAPAN TERIMA KASIH}

Pada kesempatan kali ini penulis mengucapkan terimakasih kepada Kepala Balai Besar Wilayah Sungai (BBWS) Serayu-Opak yang telah memfasilitasi penyediaan lokasi dan data dalam penelitian ini. Terimakasih juga kami ucapkan kepada LPPM-Universitas Gadjah Mada dan Direktorat Pendidikan Tinggi Kementrian Riset dan Pendidikan Tinggi yang telah memberikan dana penelitian sehingga pekerjaan ini bisa berjalan dengan lancar. Tak lupa kepada rekan-rekan mahasiswa yang mendukung pengukuran lapangan, serta kepada Ibu Yulaikhah, Bpk Iqbal Taftazani, Ibu Nurrochmat Widjajanti dan Tim Dosen Teknik Geodesi yang telah memberikan support yang luar biasa selama pengumpulan data, kami ucapkan terimakasih. Terimakasih juga kami sampaikan kepada semua pihak yang tidak biisa kami sebutkan satupersatu yang telah membantu penelitian ini.

\section{DAFTAR PUSTAKA}

Abdurachman, A. (1989). Rainfall Erosivity and Soil Erodibility in Indonesia: Estimation and Variation with Time. University of Ghent, Belgium.

Arsyad, S. (2010). Konservasi Tanah dan Air. Institut Pertanian Bogor, Bogor: IPB Press.

Asdak, C. (1995). Hidrologi dan Pengelolaan Daerah Aliran Sungai. Yogykarta: Gadjah Mada University Press.

Bara’tau. (2012). Muatan Sedimen pada Das Tallo Hulu (Sub Das Jenepangkalung dan Sub DAS Jenetalinggoa). Skripsi. Universitas Hasanuddin. Makassar.

Departemen Kehutanan. (2009). Pedoman Monitoring dan Evaluasi Daerah Aliran Sungai. Direktorat Jenderal Rehabilitasi Lahan, Jakarta. 
Departemen Kehutanan. (2009). Pedoman Penyusunan Rencana Teknis Rehabilitasi Lahan dan Konservasi Tanah di Daerah Aliran Sungai. Direktorat Jenderal Rehabilitasi Lahan dan Perhutanan Sosial, Jakarta.

Hermiawati. (2006). Analisis Perbandingan Pendugaan Erosi Menggunakan Metode Usle dan Unit Spas pada Model Das Mikro (Studi Kasus Pada DTA Cilebak, Sub DAS Citarum Hulu). Skripsi. Institut Pertanian Bogor.

Kironoto, B. A. (2003). Transpor Sedimen. PPS-Teknik Sipil, Yogyakarta.

Lazzari, M., Gioia, D., Piccarretaa, M., Danese M., \& Lanorte, A. (2016). Sediment Yield and Erosion Rate Estimation in The Mountain Catchments of The Camastra Artificial Reservoir (Southern Italy): A Comparison Between Different Empirical Methods. CATENA, 127, 323-339. http://www.sciencedirect.com/science/article/pii/S0341816215000028,

Surat Menteri Kehutanan Nomor: SK.328/Menhut-II/2009. (2009). Penetapan Daerah Aliran Sungai (DAS) Prioritas dalam Rencana Pembangunan Jangka Menengah (RPJM) Tahun 2010-2014. Menteri Kehutanan Republik Indonesia, Jakarta.

Saygın, S.D., Ozcan, S.U., Basaran, M., Timur, O.B., Dolarslan, M., Y1lman, F.E., \& Erpul, G. (2014). The Combined RUSLE/SDR Approach Integrated with GIS and Geostatistics to Estimate Annual SedimentFlux Rates in the SemiArid Catchment, Turkey. Journal of Environment Earth Science, 71, 1605-1618, https://link.springer.com/content/ pdf/10.1007\%2Fs12665-013-2565-y.pdf

Suripin. (2002). Pelestarian Sumberdaya Tanah dan Air. Yogyakarta: Andi Offset.

Tresnawati. 1991. Prediksi Erosi dengan Menggunakan Metode USLE (Universal Soil Loss Equation) pada Beberapa Kecamatan di Kabupaten Sukabumi serta Menentukkan Pola Penanaman dan Tindakan Konservasi yang Tepat. Skripsi. Institut Pertanian Bogor. Bogor.

Wischmeier W.H., \& Smith, D.D. 1978. Predicting Rainfall Erosion Lossess: A guide to Conservation Planning USDA. Washington DC. 